\title{
Additive and Non-additive Biomass Equations for Black Wattle
}

\author{
Alexandre Behling ${ }^{1}$ (D), Sylvio Péllico Netto ${ }^{1}$ (D), \\ Carlos Roberto Sanquetta $^{1}$ (D), Ana Paula Dalla Corte ${ }^{1}$ (D), Augusto Arlindo Simon ${ }^{2}$ (D), \\ Aurélio Lourenço Rodrigues ${ }^{1}$ (D), Braulio Otomar Caron ${ }^{3}$ (i) \\ ${ }^{1}$ Universidade Federal do Paraná - UFPR, Curitiba/PR, Brasil \\ ${ }^{2}$ TANAC S.A. e TANAGRO S.A., Montenegro/RS, Brasil \\ ${ }^{3}$ Universidade Federal de Santa Maria - UFSM, Santa Maria/RS, Brasil
}

\begin{abstract}
The objectives of this work were to propose additive equations for biomass components (stem and crown) and total biomass for black wattle (Acacia mearnsii De Wild.) and show the inconsistency of independently adjusted biomass equations. Two procedures were used to fit nonlinear equations of biomass: i) independent and ii) systems of equations. The second procedure, defined by the application of the seemingly unrelated regression model, has better biological and statistical properties to estimate allometric equations of biomass components and total biomass when compared with the independent estimation. An effective property of this procedure is the additivity, i.e., the estimates of component biomass are compatible with those of total biomass. Independent fitted adjusted equations do not consider the dependence between the biomass components, thus, besides the estimates being non-additive, which is an undesirable property, they will result in estimates with larger variance.
\end{abstract}

Keywords: nonlinear seemingly unrelated regression, error modeling, additivity.

\section{Equações de Biomassa Aditivas e não Aditivas para Acácia Negra}

\begin{abstract}
RESUMO
Os objetivos desse trabalho foram propor equações aditivas de biomassa dos componentes (fuste e copa) com a biomassa total para a espécie acácia negra (Acacia mearnsii De Wild.) e demonstrar a inconsistência de equações de biomassa ajustadas independentemente. Dois procedimentos foram utilizados para ajustar equações não lineares de biomassa: i) independente e ii) sistemas de equações. O segundo procedimento, definido pela aplicação do modelo de regressão aparentemente não relacionada, apresenta melhores propriedades biológicas e estatísticas para estimar equações alométricas de biomassa dos componentes e biomassa total, quando comparado com a estimação independente. Uma propriedade efetiva desse procedimento é a aditividade, isto é, as estimativas de biomassa dos componentes são compatíveis com as de biomassa total. As equações ajustadas independentes não consideram a dependência entre os componentes de biomassa, assim, além das estimativas não serem aditivas, propriedade indesejável, resultarão em estimativas com maior variância.
\end{abstract}

Palavras-chave: regressão não linear aparentemente não relacionada, modelagem do erro, aditividade. 


\section{INTRODUCTION}

Energy generation from forest biomass has the potential to reduce carbon emissions when compared with other energy sources, especially fossil fuels. Therefore, accurate biomass estimates have been fundamental for diverse applications. Information on biomass stocks is especially useful for forest managers to determine the role of forest biomass in the global carbon cycle and to manage energy production from biomass. Hence the importance of establishing equations and enabling forest biomass inventories.

The development and testing of allometric biomass models depend on the availability of data from destructive tree evaluations and is a time-consuming and expensive task (Chave et al., 2014). To avoid this work being carried out frequently, it is possible to use existing biomass equations and to estimate biomass stocks using forest inventory information.

These equations must be established by asserting some assumptions. Genet et al. (2011) pointed out that a good set of biomass equations must meet the following characteristics: i) consistency, to ensure the additivity of the estimates between biomass components and total biomass; ii) robustness, to compose an operating system that works correctly for wide variations in the sample population and with low sensitivity to the sampling process and to the formulated hypotheses; and iii) accuracy.

Consistency can be ensured by applying the seemingly unrelated regression for linear models and its variation for non-linear models, according to Parresol $(1999,2001)$. Additive biomass equations are desirable because the estimates of the component biomass and total biomass are harmonic, overcoming the lack of consistency in the estimates.

Black wattle (Acacia mearnsii De Wild.) is one of the most grown forest trees in the state of Rio Grande do Sul. It is a versatile species with characteristics allowing the generation of economic, social, and, above all, environmental benefits. Growing black wattle forests and trading their products is a solid economic activity and, according to Stein \& Tonietto (1997), has brought benefits and prosperity to more than 40 municipalities and approximately 40 thousand families.
Equations for estimating black wattle biomass have already been proposed by several researchers, as we highlight throughout this text. In the present work a new approach is applied to fit the equations, using data from the main forest sites in the state of Rio Grande do Sul, from stands with different ages, and an expressive sample size in terms of number of trees. The new approach used to adjust equations was based on the following hypothesis: given that the estimators of equation systems include constraints to obtain the coefficients in their adjustments, their estimates might result in additivity of the components, when compared with the estimators obtained in a single equation, and therefore result in estimates of biomass components additive with estimates of total biomass.

Therefore, the objectives of this study were to propose additive equations for biomass components (stem and crown) and total biomass for black wattle and demonstrate the inconsistency of independently adjusted biomass equations.

\section{MATERIAL AND METHODS}

\subsection{Sampling in stands of black wattle}

The field research was carried out in commercial stands of black wattle (Acacia mearnsii de Wild.) in areas where the species is prevalent in the state of Rio Grande do Sul, in June and July 2014. It was possible to divide these areas into three regions: Cristal, Encruzilhada do Sul, and Piratini. These regions have their climate, relief type, and soil characterized in Mochiutti (2007).

The stands were sampled in a sequence of ages after planting, to cover all crop rotation (Table 1). Four circular plots with $10 \mathrm{~m}$ in diameter $\left(78.54 \mathrm{~m}^{2}\right)$ were randomly allocated in each stand. All trees in the plots were felled and measured for the following characteristics: diameter at breast height, total height, stem and crown biomass. The research involved the allocation of 48 temporary plots and the measurement of the characteristics on 670 trees.

The diameter at breast height (d) was measured with a dendrometric tape and the total height (h) with a tape. Biomass measurement was performed for the stem component (stem wood + bark) and 
Table 1. Group and systems of equations organized by age and maturity of the stands, ranges of independent variables $(d$ and $h)$, and number of individuals $(T)$ used to fit biomass equations in black wattle stands in the state of Rio Grande do Sul, Brazil.

\begin{tabular}{cccccc}
$\begin{array}{c}\text { Group and } \\
\text { systems of } \\
\text { equations }\end{array}$ & $\begin{array}{c}\text { Age } \\
\text { (years) }\end{array}$ & $\begin{array}{c}\text { Maturity of the } \\
\text { stands }\end{array}$ & $\boldsymbol{T}$ & $\boldsymbol{d}(\mathbf{c m})$ & $\boldsymbol{h}(\mathbf{m})$ \\
\hline 1 & 1 & Too young & 69 & $0.64-03.34$ & $1.60-04.25$ \\
\hline 2 & $1.75-1.83$ & Young & 115 & $2.23-10.66$ & $4.40-10.20$ \\
\hline 3 & $2.33-3.08$ & Medium-inicial & 163 & $2.86-16.55$ & $5.40-15.40$ \\
\hline 4 & $5-5.75$ & Medium-advanced & 153 & $2.55-18.46$ & $4.70-20.60$ \\
\hline 5 & $9.83-10.75$ & Mature & 170 & $3.82-23.55$ & $7.70-21.90$ \\
\hline
\end{tabular}

crown (live and dead branches, leaves, flowers and fruits), as defined in Picard et al. (2012). For each tree, these components were separated and weighed to obtain the wet biomass with a Portable Scale with $5 \mathrm{~g}$ of accuracy. Total biomass was defined as the sum of the stem biomass and crown components.

Samples of the components were taken and immediately weighted with a digital scale (Hoyle) with $1 \mathrm{~g}$ of accuracy. Samples of the crown, approximately $1,500 \mathrm{~g}$, were taken at positions $0 \%, 25 \%, 50 \%, 75 \%$, and $95 \%$ of the total crown length (distance of the first branch, regardless of being alive or dead, to the apex of this component). In each stem, 5 discs of $2 \mathrm{~cm}$ thick were removed at the positions: $0 \%, 25 \%, 50 \%$, $75 \%$, and $95 \%$ of the total height. The samples were dried in an oven with air-circulation and air renewed at $100^{\circ} \mathrm{C}$ to constant mass and weighed with a digital scale with 1 g of accuracy. Dry biomass was calculated from the values of biomass moisture content.

\subsection{Aboveground biomass equations}

The equations for biomass components and total aboveground biomass were proposed according to the age of the stands, as shown in Table 1. Equations estimated independently were named as equation group, and those estimated jointly as equation system.

\subsubsection{Independently estimated biomass equations: procedure 1}

The first step in the independent estimation of equations was the evaluation of the competing models, described by Behling (2016) for the input variables $d$ (in $\mathrm{cm}$ ) and $h$ (in $\mathrm{m}$ ) for crown biomass ( $y_{C}$, in $\mathrm{kg}$ ), stem biomass $\left(y_{F}\right.$, in $\left.\mathrm{kg}\right)$, and total biomass ( $y_{\text {Total }}$, in $\left.\mathrm{kg}\right)$.
The linear models were adjusted by ordinary least squares, and the nonlinear models by estimated generalized nonlinear least squares, with estimators defined by Greene (2008). The performance of each model was evaluated based on the adjusted coefficient of determination $\left(\bar{R}^{2}\right)$ and coefficient of variation $(C V)$, according to the concepts presented in Steel et al. (1996) and Greene (2008). The models selected to express the allometry of biomass components and total biomass as a function of the variables $d$ and $h$ are defined in Equations 1 and 2.

Group of equations

Models

1,2 and 3

$\hat{y}_{C}=\beta_{1}\left(d^{2} h\right)^{\beta_{2}}+\varepsilon_{C}$

$\hat{y}_{F}=\beta_{1}\left(d^{2} h\right)^{\beta_{2}}+\varepsilon_{F}$

$\hat{y}_{\text {Total }}=\beta_{1}\left(d^{2} h\right)^{\beta_{2}}+\varepsilon_{\text {Total }}$

4 and 5

$$
\begin{aligned}
& \hat{y}_{C}=\beta_{1}\left(d^{2} h\right)^{\beta_{2}}+\varepsilon_{C} \\
& \hat{y}_{F}=\beta_{1} d^{\beta_{2}} h^{\beta_{3}}+\varepsilon_{F} \\
& \hat{y}_{\text {Total }}=\beta_{1} d^{\beta_{2}} h^{\beta_{3}}+\varepsilon_{\text {Total }}
\end{aligned}
$$

White's test (1980) was applied to test the hypothesis of homogeneity of residuals in each equation, with 95\% probability. When the hypothesis was rejected, the weights were obtained through the variance structure, as defined by Harvey (1976) and Parresol (2001), followed by a new equation fitting and White's test application. The variance-covariance matrices of $b_{i}$ (where $i$ refers to the coefficient of each equation) were also presented. They are useful for making inferences about the estimation 
of parameters and confidence intervals and are calculated according to Parresol (2001).

\subsubsection{Biomass equation systems: procedure 2}

The biomass equation systems were developed for total biomass, crown biomass and stem components. The models selected for the components were those defined in [1] and [2]. The model for total biomass was defined as a function of the independent variables of each function of component $i$. Thus, the equation systems were defined according to Equations 3 and 4 .

$$
\begin{aligned}
& \hat{y}_{C}=\beta_{11}\left(d^{2} h\right)^{\beta_{12}}+\varepsilon_{C} \\
& \hat{y}_{F}=\beta_{21}\left(d^{2} h\right)^{\beta_{22}}+\varepsilon_{F} \\
& \hat{y}_{\text {Total }}=\beta_{11}\left(d^{2} h\right)^{\beta_{12}}+\beta_{21}\left(d^{2} h\right)^{\beta_{22}}+\varepsilon_{\text {Total }} \\
& \hat{y}_{C}=\beta_{11}\left(d^{2} h\right)^{\beta_{12}}+\varepsilon_{C} \\
& \hat{y}_{F}=\beta_{1} d^{\beta_{2}} h^{\beta_{3}}+\varepsilon_{F} \\
& \hat{y}_{\text {Total }}=\beta_{11}\left(d^{2} h\right)^{\beta_{12}}+\beta_{1} d^{\beta_{2}} h^{\beta_{3}}+\varepsilon_{\text {Total }}
\end{aligned}
$$

We used the model of nonlinear seemingly unrelated regressions to solve the systems of Equations 3 and 4, with parameter estimates made in SAS software. The White's test was applied to test the hypothesis of homogeneity of residuals for the component equations and the equation of the total, at $95 \%$ probability. For the cases in which the hypothesis was rejected, the weights obtained in the previous section were used and the system was adjusted again using the estimator of weighted-nonlinear seemingly unrelated regressions (WNSUR), followed by the application of the White's test. Note that the residual scatter plots were not included, since one of the objectives of the residuals analysis is already met by presenting the White's test and its interpretation. In addition, given the appropriate conditions to perform the adjustment (homogeneity of residual variances), the authors believe that it is more important to present the variance-covariance matrices, since they are useful to make several inferences, which will be shown in the following sections.

The performance of each model was evaluated based on the adjusted coefficient of determination $\left(\bar{R}^{2}\right)$ and coefficient of variation $(C V)$, according to Steel et al. (1996). The variance-covariance matrices of $b_{i j}$ (in which $i$ is the coefficient between the equations and $j$ the coefficients of each equation), are calculated according to Parresol (2001). These matrices were presented because they show the correlations between the components measured in the same tree, i.e., the dependence between the biomass components. These correlations will determine the gains in efficiency owing to the application of WNSUR. In addition, these matrices are needed for applications combined with the fitted equations in order to make inferences about the confidence intervals of the estimates.

\section{RESULTS}

\subsection{Independently estimated biomass equations: procedure 1}

The null hypothesis of homogeneity of the residuals was rejected for most equations, according to the White's test. Thus, we obtained the weights for the biomass of the components and total biomass using the structures of variance in Equations 5 to 19. For the equations with null hypothesis accepted, the weights were considered equal to one.

\section{Group 1}

$y_{c}: \hat{\sigma}^{2}=1$

$y_{F}: \hat{\sigma}^{2}=1$

$y_{\text {Total }}: \hat{\sigma}^{2}=1$

Group 2

$y_{c}: \hat{\sigma}^{2}=1$

$y_{F}: \hat{\sigma}^{2}=\left(d^{2} h\right)^{0.856511}$

$y_{\text {Total }}: \hat{\sigma}^{2}=\left(d^{2} h\right)^{0.485465}$

Group 3

$y_{c}: \hat{\sigma}^{2}=\left(d^{2} h\right)^{1.264866}$

$y_{F}: \hat{\sigma}^{2}=\left(d^{2} h\right)^{1.334049}$

$y_{\text {Total }}: \hat{\sigma}^{2}=\left(d^{2} h\right)^{1.670747}$

Group 4

$y_{c}: \hat{\sigma}^{2}=\left(d^{2} h\right)^{0.945054}$

$y_{F}: \hat{\sigma}^{2}=d^{4.002528} h^{-0.716350}$ 


$$
y_{\text {Total }}: \hat{\sigma}^{2}=d^{3.539289} h^{0.052788}
$$

Group 5

$$
\begin{aligned}
& y_{c}: \hat{\sigma}^{2}=\left(d^{2} h\right)^{1.236776} \\
& y_{F}: \hat{\sigma}^{2}=d^{4.514350} h^{-0.595380} \\
& y_{\text {Total }}: \hat{\sigma}^{2}=d^{4.786551} h^{-0.249140}
\end{aligned}
$$

The statistics of the equations adjusted by procedure 1 and complemented with the weighting are shown in Equations 20 to 34 . The correction of heteroscedasticity was evidenced by the weighting via White's test and residual graphic analysis. In addition, all coefficients were significant at $95 \%$ probability by application of $t$-test.

$\bar{R}^{2}$ CV White

Group 1

$$
\begin{aligned}
& \hat{y}_{C}=0.215867\left(d^{2} h\right)^{0.445297} 69.22 \% 22.11 \% 3.03^{n s} \\
& \hat{y}_{F}=0.178804\left(d^{2} h\right)^{0.500678} 83.98 \% 16.13 \% 10.01^{n s} \\
& \hat{y}_{\text {Total }}=0.394430\left(d^{2} h\right)^{0.471904} 81.19 \% 16.86 \% 2.05^{n s}
\end{aligned}
$$

Group 2

$$
\begin{aligned}
& \hat{y}_{C}=0.0328047\left(d^{2} h\right)^{0.826434} 64.07 \% 31.51 \% 1.71^{n s} \\
& \hat{y}_{F}=0.051673\left(d^{2} h\right)^{0.839463} 92.94 \% 12.45 \% 13.02^{n s} \\
& \hat{y}_{\text {Total }}=0.086821\left(d^{2} h\right)^{0.830291} 89.28 \% 15.27 \% 4.84^{n s}
\end{aligned}
$$

Group 3

$$
\begin{aligned}
& \hat{y}_{C}=0.003410\left(d^{2} h\right)^{1.077143} 89.80 \% 24.86 \% 1.38^{n s} \\
& \hat{y}_{F}=0.039333\left(d^{2} h\right)^{0.900797} 95.24 \% 13.39 \% 6.86^{n s} \\
& \hat{y}_{\text {Total }}=0.037582\left(d^{2} h\right)^{0.944718} 95.94 \% 12.99 \% 1.67^{n s}
\end{aligned}
$$

Group 4

$$
\begin{aligned}
& \hat{y}_{C}=0.005891\left(d^{2} h\right)^{0.976956} 80.70 \% 29.58 \% 6.97^{n s} \\
& \hat{y}_{F}=0.048390 d^{2.033388} h^{0.667959} 95.19 \% 13.34 \% 6.69^{n s} \\
& \hat{y}_{\text {Total }}=0.062245 d^{2.102267} h^{0.591272} 95.43 \% 13.58 \% 6.04^{n s}
\end{aligned}
$$

\section{Group 5}

$$
\begin{aligned}
& \hat{y}_{C}=0.000778\left(d^{2} h\right)^{1.214249} 82.89 \% 38.42 \% 4.67^{n s} \\
& \hat{y}_{F}=0.039145 d^{1.984245} h^{0.829223} 95.73 \% 13.41 \% 8.58^{n s}
\end{aligned}
$$

$\hat{y}_{\text {Total }}=0.057760 d^{2.139698} h^{0.611213} 95.95 \% 13.75 \% 4.84^{n s} \quad(34)$

The variance-covariance matrices of $b_{i j}$ (where $i$ is the coefficient of each equation) for each group are presented in the supplementary material.

\subsection{Biomass equation systems: procedure 2}

Heteroscedasticity was confirmed for the same previous cases by the rejection of the null hypothesis via White's test. Therefore, the new fitting of the functions was carried out using procedure 2 , with the application of the weights already obtained in procedure 1 . The new equations and the resulted statistics are shown in Equations 35 to 49 . The correction of heteroscedasticity was evidenced by the weighting via White's test and residual graphic analysis. All adjusted coefficients were significant at $95 \%$ probability by application of $t$-test.

$\bar{R}^{2} C V$ White

System 1

$\hat{y}_{C}=0.205422\left(d^{2} h\right)^{0.459328} 69.58 \% 21.98 \% 2.57^{n}$

$\hat{y}_{F}=0.17493\left(d^{2} h\right)^{0.506569} 84.19 \% 16.03 \% 9.63^{n s}$

$\hat{y}_{\text {Total }}=\hat{y}_{C}+\hat{y}_{F} 81.15 \% 16.88 \% 1.65^{n s}$

System 2

$\hat{y}_{C}=0.032844\left(d^{2} h\right)^{0.827296} 64.37 \% 31.38 \% 1.77^{n s}$

$\hat{y}_{F}=0.052046\left(d^{2} h\right)^{0.837992} 92.99 \% 12.41 \% 11.93^{n s}$

$\hat{y}_{\text {Total }}=\hat{y}_{C}+\hat{y}_{F} 89.29 \% 15.26 \% 4.78^{n s}$

System 3

$\hat{y}_{C}=0.003320\left(d^{2} h\right)^{1.079325} 89.84 \% 24.81 \% 1.28^{n s}$

$\hat{y}_{F}=0.039548\left(d^{2} h\right)^{0.899084} 95.31 \% 13.30 \% 6.06^{n .}$

$\hat{y}_{\text {Total }}=\hat{y}_{C}+\hat{y}_{F} 95.97 \% 12.95 \% 1.62^{n s}$

System 4

$\hat{y}_{C}=0.004438\left(d^{2} h\right)^{1.010899} 80.58 \% 29.67 \% 6.33^{n s}$

$\hat{y}_{F}=0.051517 d^{1.979083} h^{0.692747} 95.24 \% 13.32 \% 6.21^{n s}$

$\hat{y}_{\text {Total }}=\hat{y}_{C}+\hat{y}_{F} 95.38 \% 13.15 \% 12.11^{n s}$

System 5

$\hat{y}_{C}=0.001216\left(d^{2} h\right)^{1.165186} 82.39 \% 38.98 \% 5.37^{n s}$ 


$$
\begin{aligned}
& \hat{y}_{F}=0.053628 d^{1.967389} h^{0.736520} 95.84 \% 13.24 \% 6.63^{n s} \\
& \hat{y}_{\text {Total }}=\hat{y}_{C}+\hat{y}_{F} 95.86 \% 13.89 \% 9.15^{n s}
\end{aligned}
$$

The variance-covariance matrices of $b_{i j}$ (where $i$ is the coefficient of each equation) for each group are presented in the supplementary material.

\section{DISCUSSION}

\subsection{Nonlinear biomass equations}

The biomass components and total biomass were modeled by non-linear biomass functions. The adjustment of these functions requires more demanding computational methods, although their implementation is made possible by the low operational cost currently available in computers and softwares. Therefore, the use of nonlinear equations is not a limiting factor and provides certain positive conditions that are not achieved through linear regression, although there must be attention to ensure if appropriate functions are obtained.

In this work, biomass was modeled in the original (nonlinear) form for the following reasons: the relationship between dependent and independent variables are non-linear; model linearization causes an inherent bias in the transformation of data in relation to the original arithmetic scale, thus correction is necessary; the application of nonlinear models allows the use of the original values not implying in data transformation as in the cases of model linearization; nonlinear models are better than linear models.

Although certain positive aspects of the nonlinear approach are highlighted, it also provides some challenges in relation to the linear approach. It is often necessary to work on the convergence criteria to avoid premature stopping of the iterations and a subsequent loss of precision of the resulted coefficients. This requires a more experienced modeler, compared to the use of linear models. In the nonlinear approach, the first challenge refers to the estimates of the initial parameters that must be specified, and experience is required to define them or, where possible, by means of a consistent $\beta$ vector. In this condition, the functions must be linearized and adjusted by ordinary least squares to obtain the initial values, as performed in this work. The second challenge refers to which algorithm to use in the iteration process, such as Gauss-Newton and Marquardt.

Failures in convergence processes reveal other challenges in the nonlinear approach. According to Parresol (2001), they can occur for several reasons and the most important ones are: partial derivative matrix and direction matrix can be singular, indicating that the model can be over-parameterized; it is possible for the parameters to occur in a numerical space in which the logarithmic and square root arguments are not valid, resulting in excess of calculations. Logically, these problems can be avoided by the careful choice of models and the establishment of different initial $\beta$ vectors.

There are still other difficulties, that is, the iteration method can lead to steps that do not improve the estimates. In this case, according to Parresol (2001), the length of step $l_{n}$ needs to be controlled to change the starting values or to choose another iteration method. The result of the gradient should also be considered it may cause small changes in the residual sum of squares and (or) small changes in the parameter estimates with successive iterations, but still be far from the solution.

\subsection{Modeling of variance structure}

Heteroscedasticity of residuals is common in the modeling of tree biomass, and it has been reported by several researchers: Parresol (1999, 2001), Saint-André et al. (2005), Basuki et al. (2009), Bi et al. (2010), Sileshi (2014), Wayson et al. (2015), Sanquetta et al. (2015b), and Zhao et al. (2015). Cunia \& Briggs (1984) pointed out that it is natural to expect that the biomass variability of trees with smaller diameters is smaller than the biomass variability of trees with larger diameters, leading to the variance of residuals to be non-constant for the biomass equations.

This should not be ignored when fitting equations by regression analysis. Constant variance is fundamental in regression analysis, since it directly affects the validation of several hypotheses tested, as demonstrated in Maddala (2001) and Greene (2008). Under heteroscedasticity of residuals two approaches can be applied to establish constant variance. The first one refers to the application of logarithmic transformation, and the second one of regression weighting. In regression weighting, instead of using simple weights such as $d^{-1}, h^{-1}$ and $\left(d^{2} h\right)^{-1}$, 
the approach by modeling the variance structure is more appropriate (Parresol, 1993, 1999, 2001).

The logarithmic transformation to correct heteroscedasticity is an approach easier and faster than applying regression weight, because it does not require the modeling of the variance structure. However, it reverts to problems already evidenced, caused by data transformation. For these reasons, it is logical to model the variance structure instead of applying logarithmic or even another transformation. Parresol (2001) also recommended modeling the error variance structure rather than using the logarithmic transformation to correct the heteroscedasticity of biomass data. He demonstrated that transformed or weighted equations for stem and bark biomass resulted in similar standard errors of the coefficients and in the statistics used for evaluation of goodness-of-fit. However, for crown biomass and total biomass, the weighted equations showed better results for standard error of the coefficients and prediction intervals of the estimates. The transformed equations resulted in slightly more elastic prediction intervals, but this would have a greater impact if considered the cumulative effect by applying the equations to hundreds or thousands of trees.

Using the variance structure, we established the weights and readjusted the equations. This led to the stabilization of variance, hence the weighted functions allowed the homoscedasticity of residuals. Homoscedasticity is indispensable to obtain appropriate confidence intervals and to validate the hypothesis tests. An effect of achieving constant variance is observed when the standard errors of the coefficients are smaller than those obtained under heteroscedasticity of the residuals (although these results were not presented in this manuscript), which was also observed by Parresol $(1999,2001)$.

\subsection{Aboveground tree biomass equations for black wattle}

The coefficients of variation for the equations of the crown component were greater than those evaluated for the equations of stem and total components, because the crown biomass (composed by biomass of leaves and branches) presents more variability on allometric relationship with the independent variables. Poorter et al. (2012) reported an interesting discussion about biomass allocation to leaves, stems, and roots. The authors discussed the pattern of variation of these components and how their growth is influenced by the environment, plant size, dynamic process, and competition. It is known that the evolutionary patterns of plants are influenced by environmental conditions and, therefore, this reflects on the proportions among tree components, as well as in their allometry, i.e., the allometric relationship of the crown and stem components with the independent variables should not be the same, because their biomass proportions are different when equated to the same independent variable.

Adjusted coefficients of determination and variation from the fitted equations through procedures 1 and 2 are within the range obtained in other black wattle studies. Coefficients of determination greater than $80 \%$ for black wattle biomass equations have been frequently reported in the literature, with approaches developed by several researchers: Dudley \& Fownes (1992), Carbonera Pereira et al. (1997), Caldeira (1998), Barichello et al. (2005), Saidelles (2005), Mochiutti (2007), Caldeira et al. (2011), and Sanquetta et al. (2014).

The coefficients estimated from equations of biomass components via procedures 1 and 2 led to close relationship with the groups or systems of equations, determined according to the stand age. This finding was also evidenced by Williams et al. (2003), who observed that the allometry of the components was not the same for populations of the same species with different ages. The authors pointed out that stand age influences the relationship between biomass and the variables that express tree dimensions such as $d$ and $h$, as discussed by Niklas (1995).

Saint-André et al. (2005) also found that the parameters estimated from the biomass models varied clearly with the stand age. They argued that this is not only a result of a change in tree maturity, but rather a combined effect of the tree age and its sociological position. The authors observed that two trees with same $d$ and $h$, but with different ages, show differences in their sociological position. In this case, the younger tree may be dominant, while the older tree is likely to be suppressed. Thus, both effects, age and sociological position, cause an increase in stem biomass of the oldest tree. This occurs because the wood density increases with the stand age and the form 
factor (ratio between stem volume and $\frac{\pi}{4} d^{2} h$ ), which is higher in dominated trees. On the other hand, both effects tend to decrease the biomass of live leaves and branches of old and suppressed trees, because most leaves are allocated in the periphery of the crown. Other reason is that the crown height is strongly reduced depending on its sociological position.

In addition, there is the effect of the biomass components allocation, which varies with the stand age, being also a common characteristic. In this study, the proportion of stem biomass in relation to the total biomass increased as a function of age, i.e., from the very young to mature forest, while the proportion of the crown biomass in relation to the total biomass decreased.

Therefore, the development of biomass equations according to age range can benefit forest managers when evaluating biomass stocks per component.

All intercept and exponential coefficients of the equations were significant. The intercept values were higher for the groups or systems of equations adjusted for the younger stands than for the older ones. Angular coefficients behave inversely. This inverse proportion relationship between the intercept and the angular coefficients was also observed by Fehrmann \& Kleinn (2006), Zianis (2008), Zapata-Cuartas et al. (2012), and Sileshi (2014) and thoroughly discussed by Pilli et al. (2006).

The dependence of the coefficients of the biomass equations on the stand ages is fundamental to generalize the black wattle biomass equations. The generalization of the equations - when they are adjusted for data from regional, state and national forest inventories increases in importance and aims to create equations for various species, sites and ages. Generalization facilitates the application of the equations, because they are robust and present fewer restrictions, mainly owing to regional characteristic and age range of the tree sampling trees. In this scenario, the possibilities of using generalized biomass equations in the present case are clear, especially because stratification by age is not required anymore. Although this is an important theme, it was not considered in this work. We considered age stratification previous to define the equations.

The equations presented in this work are intended to be used in biomass inventories of black wattle stands and come from the main grown sites in the state of Rio Grande do Sul, covering a wide range of stand ages.
Additional information regarding the variance-covariance matrix of coefficients and residuals was included in the appendix. Therefore, these equations are useful for inventories of biomass components and total biomass, specially the equations fitted by procedure 2 for equation systems.

The application of the equations independently adjusted (procedure 1) is not appropriate because they generate biologically inconsistent results, referred here as loss of compatibility between biomass components and total biomass. Most equations developed for black wattle and other species in Brazilian forests were independently adjusted. These equations are not additive and certain precautions should be considered before using them.

Biomass estimation for forest inventory purposes should use equations adjusted via procedure 2 . These equations result in additivity of the estimates between biomass components and total biomass, a desirable and fundamental characteristic in modeling the biomass of trees. Ensuring additivity in tree biomass estimates has been recommended by several authors: Kozak (1970), Chiyenda \& Kozak (1984), Cunia \& Briggs (1984), Parresol (1999, 2001), Carvalho \& Parresol (2003), Dong et al. (2014), Bi et al. (2015), Sanquetta et al. (2015a), Zhao et al. (2015), Zheng et al. (2015), Affleck \& Diéguez-Aranda (2016), and Poudel \& Temesgen (2016). In this study, additivity of the components to compose the total biomass was ensured using procedure 2 . An equation for each biomass component was obtained, and the equation for the total biomass was composed with the same variables and coefficients of the equations fitted to the components.

\section{CONCLUSIONS}

Using nonlinear equations is appropriate because they are more accurate than linear equations.

WNSUR model presents better biological and statistical properties for estimating allometric equations of biomass components and total biomass than the independent estimation. Therefore, it should be used in forest inventories.

The independent fitted equations result in non-additivity of the estimates between biomass components and total biomass, an undesirable property. Moreover, they will 
result in greater variance estimates than those obtained by WNSUR equations.

Performing the modeling of variance structure and adjusting weighted equations is important to ensure reliable estimates of each biomass component and total biomass with minimum variance.

\section{SUBMISSION STATUS}

Received: 6 apr., 2017

Accepted: 27 oct., 2017

\section{CORRESPONDENCE TO}

\author{
Alexandre Behling \\ Universidade Federal do Paraná - UFPR, Av. \\ Pref. Lothário Meissner, 900, CEP 80210-170, \\ Curitiba, PR, Brasil \\ e-mail: alexandre.behling@yahoo.com.br
}

\section{FINANCIAL SUPPORT}

The authors thank the TANAGRO S.A company for cession of the data and CNPq for granting a scholarship to one of the authors.

\section{REFERENCES}

Affleck DLR, Diéguez-Aranda U. Additive nonlinear biomass equations: a likelihood-based approach. Forest Science 2016; 62(1): 129-140. http://dx.doi.org/10.5849/ forsci.15-126.

Barichello LR, Schumacher MV, Vogel MLM. Quantificação da biomassa de Acacia mearnsii De Wild na região sul do Brasil. Ciência Florestal 2005; 15(2): 129-135. http:// dx.doi.org/10.5902/198050981830.

Basuki TM, Van Laake PE, Skidmore AK, Hussin YA. Allometric equations for estimating the above-ground biomass in tropical lowland Dipterocarp forest. Forest Ecology and Management 2009; 257(8): 1684-1694. http:// dx.doi.org/10.1016/j.foreco.2009.01.027.

Behling A. Modelagem da biomassa de árvores para assegurar aditividade dos seus componentes [tese]. Curitiba: Universidade Federal do Paraná; 2016.

Bi H, Long Y, Turner J, Lei Y, Snowdon P, Li Y et al. Additive prediction of aboveground biomass for Pinus radiata (D. Don) plantations. Forest Ecology and Management 2010; 259(12): 2301-2314. http://dx.doi.org/10.1016/j. foreco.2010.03.003.
Bi H, Murphy S, Volkova L, Weston C, Fairman T, Li Y et al. Additive biomass equations based on complete weighing of sample trees for open eucalypt forest species in southeastern Australia. Forest Ecology and Management 2015; 349: 106-121. http://dx.doi.org/10.1016/j.foreco.2015.03.007.

Caldeira MVW, Saidelles FLF, Schumacher MV, Godinho TO. Biomassa de povoamento de Acacia mearnsii De Wild., Rio Grande do Sul, Brasil. Scientia Forestalis 2011; 39(90): 133-141.

Caldeira MVW. Quantificação da biomassa e do conteúdo de nutrientes em diferentes procedências de Acácia-negra (Acacia mearnsii De Wild) [dissertação]. Santa Maria: Universidade Federal de Santa Maria; 1998.

Carbonera Pereira J, Schumacher MV, Hoppe JM, Caldeira MVW, Santos EM. Produção de biomassa em um povoamento de Acacia mearnsii De Wild. no Estado do Rio Grande do Sul. Revista Árvore 1997; 21(4): 521-526.

Carvalho JP, Parresol BR. Additivity in tree biomass components of Pyrenean oak (Quercus pyrenaica Willd.). Forest Ecology and Management 2003; 179(1-3): 269-276. http://dx.doi.org/10.1016/S0378-1127(02)00549-2.

Chave J, Réjou-Méchain M, Búrquez A, Chidumayo E, Colgan MS, Delitti WBC et al. Improved allometric models to estimate the aboveground biomass of tropical trees. Global Change Biology 2014; 20(10): 3177-3190. http://dx.doi.org/10.1111/gcb.12629. PMid:24817483.

Chiyenda SS, Kozak A. Additivity of component biomass regression equations when the underlying model is linear. Canadian Journal of Forest Research 1984; 14(3): 441-446. http://dx.doi.org/10.1139/x84-078.

Cunia T, Briggs RD. Forcing additivity of biomass tables: some empirical results. Canadian Journal of Forest Research 1984; 14(3): 376-384. http://dx.doi.org/10.1139/x84-067.

Dong L, Zhang L, Li F. A compatible system of biomass equations for three conifer species in Northeast, China. Forest Ecology and Management 2014; 329: 306-317. http:// dx.doi.org/10.1016/j.foreco.2014.05.050.

Dudley NS, Fownes JH. Preliminary biomass equations for eight species of fast-growing tropical trees. Journal of Tropical Forest Science 1992; 5(1): 68-73.

Fehrmann L, Kleinn C. General considerations about the use of allometric equations for biomass estimation on the example of Norway spruce in central Europe. Forest Ecology and Management 2006; 236(2-3): 412-421. http:// dx.doi.org/10.1016/j.foreco.2006.09.026.

Genet A, Wernsdörfer H, Jonard M, Pretzsch H, Rauch $\mathrm{M}$, Ponette $\mathrm{Q}$ et al. Ontogeny partly explains the apparent heterogeneity of published biomass equations for Fagus sylvatica in central Europe. Forest Ecology and Management 2011; 261(7): 1188-1202. http://dx.doi.org/10.1016/j. foreco.2010.12.034.

Greene WH. Econometric analysis. Upper Saddle River: Prentice-Hall; 2008. 
Harvey AC. Estimating regression models with multiplicative heteroscedasticity. Econometrica 1976; 44(3): 461-465. http://dx.doi.org/10.2307/1913974.

Kozak A. Methods of ensuring additivity of biomass components by regression analysis. Forestry Chronicle 1970; 46(5): 402-404. http://dx.doi.org/10.5558/tfc46402-5.

Maddala GS. Introduction to econometrics. 3rd ed. New York: John Wiley \& Sons; 2001.

Mochiutti S. Produtividade e sustentabilidade de plantações de acácia-negra (Acacia mearnsii De Wild.) no Rio Grande do Sul [tese]. Curitiba: Universidade Federal do Paraná; 2007.

Niklas KJ. Size-dependent allometry of tree height, diameter and trunk-taper. Annals of Botany 1995; 75(3): 217-227. http://dx.doi.org/10.1006/anbo.1995.1015.

Parresol BR. Modeling multiplicative error variance: an example predicting tree diameter from stump dimensions in bald cypress. Forest Science 1993; 39(4): 670-679.

Parresol BR. Assessing tree and stand biomass: a review with examples and critical comparisons. Forest Science 1999; 45: 573-593.

Parresol BR. Additivity of nonlinear biomass equations. Canadian Journal of Forest Research 2001; 31(5): 865-878. http://dx.doi.org/10.1139/x00-202.

Picard N, Saint-André L, Henry M. Manual for building tree volume and biomass allometric equations: from field measurement to prediction. Rome: Food and Agricultural Organization of the Unites Nations, Centre de Coopération Internationale en Recherche Agronomique pour le Développement; 2012.

Pilli P, Anfodillo T, Carrer M. Towards a functional and simplified allometry for estimating forest biomass. Forest Ecology and Management 2006; 237(1-3): 583-593. http:// dx.doi.org/10.1016/j.foreco.2006.10.004.

Poorter H, Niklas KJ, Reich PB, Oleksyn J, Poot P, Mommer L. Biomass allocation to leaves, stems and roots: metaanalyses of interspecific variation and environmental control. The New Phytologist 2012; 193(1): 30-50. http://dx.doi. org/10.1111/j.1469-8137.2011.03952.x. PMid:22085245.

Poudel KP, Temesgen H. Methods for estimating aboveground biomass and its components for Douglasfir and lodgepole pine trees. Canadian Journal of Forest Research 2016; 46(1): 77-87. http://dx.doi.org/10.1139/ cjfr-2015-0256.

Saidelles FLF. Determinação da biomassa e altura de amostragem para a quantificação de nutrientes em Acacia mearnsii De Wild [tese]. Santa Maria: Universidade Federal de Santa Maria; 2005.

Saint-André L, M'Bou AT, Mabiala A, Mouvondy W, Jourdan C, Roupsard O et al. Age-related equations for above - and below: ground biomass of a Eucalyptus hybrid in Congo. Forest Ecology and Management 2005; 205(1-3): 199-214. http://dx.doi.org/10.1016/j.foreco.2004.10.006.
Sanquetta CR, Behling A, Corte AP, Simon A, Pscheidt $\mathrm{H}$, Ruzza MS et al. Estoques de biomassa e carbono em povoamentos de acácia negra em diferentes idades no Rio Grande do Sul. Scientia Forestalis 2014; 42(103): 361-370.

Sanquetta CR, Behling A, Corte APD, Péllico S No, Schikowski AB, Amaral M. Simultaneous estimation as alternative to independent modeling of tree biomass. Annals of Forest Science 2015a; 72(8): 1099-1112. http:// dx.doi.org/10.1007/s13595-015-0497-2.

Sanquetta CR, Wojciechowski J, Dalla Corte AP, Behling A, Péllico S No, Rodrigues AL et al. Comparison of data mining and allometric model in estimation of tree biomass. BMC Bioinformatics 2015b; 16(247): 1-9. PMid:26250142.

Sileshi GW. A critical review of forest biomass estimation models, common mistakes and corrective measures. Forest Ecology and Management 2014; 329: 237-254. http:// dx.doi.org/10.1016/j.foreco.2014.06.026.

Steel RGD, Torrie JH, Dickey DA. Principles and procedures of statistics: a biometrical approach. 3rd ed. New York: McGraw-Hill; 1996.

Stein PP, Tonietto L. Black wattle silviculture in Brazil. In: Brown AG, Ko HC, editors. Black wattle and its utilization. Barton: Rural Industries Research and Development Corporation; 1997.

Wayson CA, Johnson KD, Cole JA, Olguín MI, Carrillo OI, Birdsey RA. Estimating uncertainty of allometric biomass equations with incomplete fit error information using a pseudo-data approach: methods. Annals of Forest Science 2015; 72(6): 825-834. http://dx.doi.org/10.1007/ s13595-014-0436-7.

Williams CJ, LePage BA, Vann DR, Tange T, Ikeda H, Ando $\mathrm{M}$ et al. Structure, allometry, and biomass of plantations Metasequoia glyptostroboides in Japan. Forest Ecology and Management 2003; 180(1-3): 287-301. http://dx.doi. org/10.1016/S0378-1127(02)00567-4.

Zapata-Cuartas M, Sierra C, Alleman L. Probability distribution of allometric coefficients and Bayesian estimation of aboveground tree biomass. Forest Ecology and Management 2012; 277: 173-179. http://dx.doi. org/10.1016/j.foreco.2012.04.030

Zhao D, Kane M, Markewitz D, Teskey R, Clutter M. Additive tree biomass equations for mid-rotation loblolly pine plantations. Forest Science 2015; 61(4): 613-623. http://dx.doi.org/10.5849/forsci.14-193.

Zheng C, Mason EG, Jia L, Wei S, Sun S, Duan J. A singletree additive biomass model of Quercus variabilis Blume forest in North China. Trees 2015; 29(3): 705-716. http:// dx.doi.org/10.1007/s00468-014-1148-1.

Zianis D. Predicting mean aboveground forest biomass and its associated variance. Forest Ecology and Management 2008; 256(6): 1400-1407. http://dx.doi.org/10.1016/j. foreco.2008.07.002. 